\title{
The water quality and metal concentrations of Cempaka Lake, Selangor, Malaysia
}

\author{
K. S. Said, M. Shuhaimi \& A. Kutty \\ School of Environmental and Natural Resource Sciences, \\ Faculty of Science and Technology, \\ Universiti Kebangsaan Malaysia, Malaysia
}

\begin{abstract}
A study of water quality parameters in Cempaka Lake was conducted in January, April, July, and October 2010. The water quality parameters such as temperature, conductivity, total dissolved solid, dissolved oxygen, $\mathrm{pH}$, and water hardness were determined. Six metals i.e. cadmium, chromium, lead, nickel, zinc, and copper were also determined. The water samples were collected randomly from different sampling points around the lake. The water quality parameters were compared with National Water Quality Standard (NWQS Malaysia) whereas metal concentrations were compared with international standards. Study showed that the water temperature and conductivity values increased during the months of the study with the averages of $27.6^{\circ} \mathrm{C}$ and $1709 \mu \mathrm{S} / \mathrm{cm}$ respectively. The dissolved oxygen and $\mathrm{pH}$ values were within the normal ranges with the averages of $1.00 \mathrm{mg} / \mathrm{l}$ and 7.37 respectively while the total dissolved solid values increased during the study period with the average of $896 \mathrm{mg} / \mathrm{l}$. Furthermore, hardness values indicated that the water of the lake classified as soft water with the average of $34.3 \mathrm{CaCo}_{3} \mathrm{mg} / \mathrm{l}$. For water quality parameters, study showed that all parameters were in natural concentration range (class I) according to National Water Quality Standard (NWQS Malaysia) except for conductivity, total dissolved solid and dissolved oxygen values. Results showed that the mean metal concentrations (in micrograms per liter) in Cempaka Lake water based on monthly sampling (in descending order) for $\mathrm{Zn}, \mathrm{Cu}, \mathrm{Ni}, \mathrm{Cr}, \mathrm{Pb}$, and $\mathrm{Cd}$ were $11.08,3.41,2.80,2.43,0.49$ and $0.24 \mu \mathrm{g} / \mathrm{L}$ respectively. Results showed that metals concentrations were lower than maximum concentrations allowed by Malaysian and international standards in protecting aquatic life.
\end{abstract}

Keywords: heavy metals, concentration, water quality, Cempaka Lake. 


\section{Introduction}

Metals have been used in various human activities since thousands of years ago and metal pollution in the aquatic environment has been an issue. Malaysia as a developing country, finds it inevitable avoiding this problem. The existence of metals concentration in the environment could be of natural causes or anthropogenic. The natural causes could be weathering; climate changes (wind and temperature) inflicted on igneous and metamorphic rocks. However the burning of fossil fuels, mining, melting minerals, industrial wastes, the use of fertilizers and pesticides in the agriculture are the main contribution of anthropogenic sources (Kendrick et al. [1]). In the context of environmental pollution, the existence of metal pollution and the existence of metal concentration could be categorized into 3 important types; non-critical, undiluted toxic metals which hardly exist and toxic metal concentrations which are widely used (Forstner and Wittman [2]). Unlike organic pollution, toxic metals could be not eliminated through biodegradable process and the impact of toxic metals could remain permanently in the environment. In some heavy metals such as Mercury and Cadmium, are known to have toxic effect although they have low concentrations (Forstner and Wittman [2]).

Heavy metal concentrations in aquatic ecosystems are usually monitored by measuring its concentration in water and biota (Camusso et al. [3]) which generally exist in low levels in water and attain considerable concentrations in biota (Namminga and Wilhm [4]). Heavy metals including both essential and non- essential elements have a particular significance in ecotoxicology, since they are highly persistent and all have the potential to be toxic to living organisms (Storelli et al. [5]).

Heavy metals do not exist in soluble forms for a long time in waters; they are present mainly as suspended colloids or are fixed by organic and mineral substances (Kabata-Pendias and Pendias [6]). In aquatic ecosystems, water contamination by heavy metals is one of the main types of pollution that may stress the biotic community (Baldantoni et al. [7]).

Cempaka Lake gardens are one of the newest recreational parks. Therefore, it is important for this study to take place in order to detect the status of the water quality especially from metal concentrations for the purpose of maintaining the metal concentrations of the lake. The objective of this research is to identify the status of the metal concentrations and the water quality parameters of Cempaka Lake, Selangor.

\section{Material and method}

\subsection{Study area}

Cempaka Lake is a man-made freshwater lake located near Taman Rekreasi. It is geographically located at $2^{\circ} 57^{\prime} 40^{\prime \prime} \mathrm{N}$ and at $101^{\circ} 45^{\prime} 20^{\prime \prime} \mathrm{E}$.

Cempaka Lake gardens are one of the newest recreational parks. Its depth is 20 meters. It covers 8 acres. The water supply comes from the rain water and 


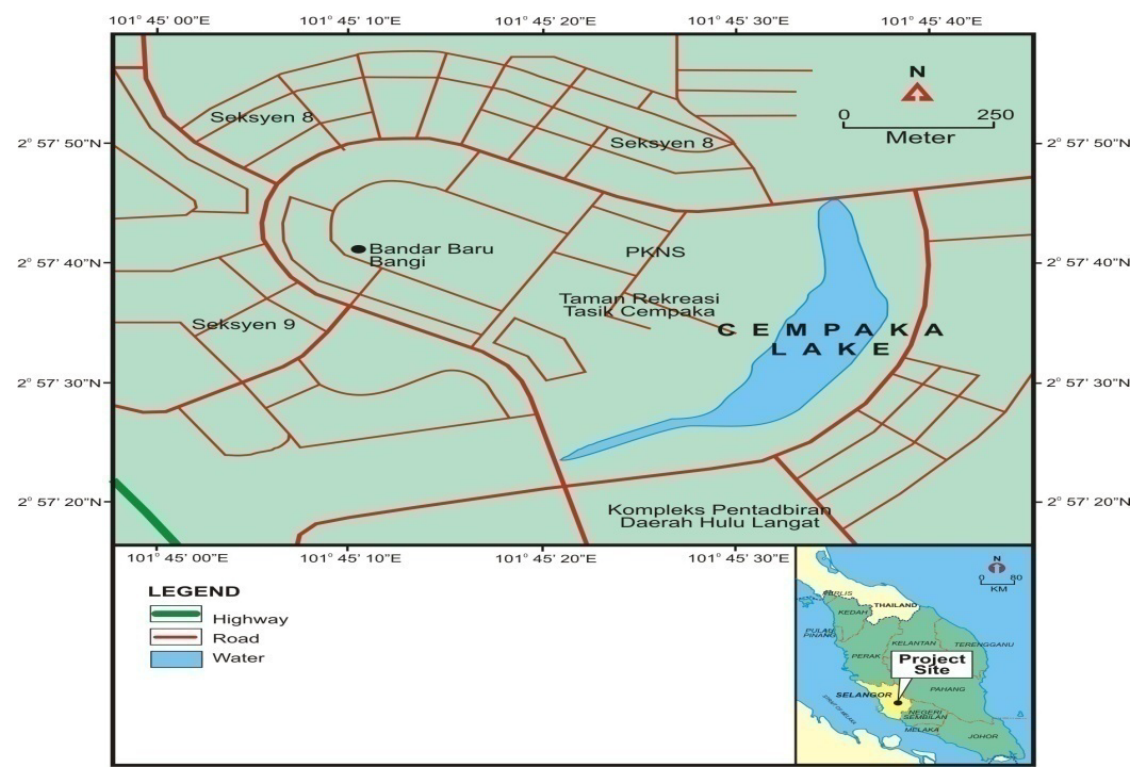

Figure 1: $\quad$ Map of Cempaka Lake.

sewage water from the adjacent restaurants and drainage finally through spillways to Langat River.

\subsection{Water and metals sampling}

The study samples were conducted during January, April, July, and October 2010. The water samples were collected from the surface at random sampling points around the lake. Triplicate water sample for metal concentrations were collected using $60 \mathrm{ml}$ polyethylene bottle and stored in a cool dark place $\left(4^{\circ} \mathrm{C}\right)$. In the laboratory, they were preserved with nitric acid $(70 \%)$ to $\mathrm{pH}<2$ and kept in the cool storage $\left(4^{\circ} \mathrm{C}\right)$ until analyzed. Water quality parameters were tested and recorded for temperature, $\mathrm{pH}$, dissolved oxygen, conductivity and total dissolved solid using Hydrolab Data Sonde $4^{\circledR}$. Metal concentrations samples were analyzed using the Inductively Coupled Plasma Mass Spectrometer (ICPMS) Perkin Elmer Elan 9000 model. Six metals in the water samples; i.e. cadmium, chromium, lead, zinc, nickel and copper were analyzed. For hardness, concentrations of $\mathrm{Ca}$ and $\mathrm{Mg}$ were determined by using the ICP-MS and the method of calculation using the APHA [8].

\subsection{Statistical analysis}

Pearson's correlation coefficients $(r)$ were used when calculating correlations between water quality parameters and concentration of heavy metals. To determine the significant differences at different months a one-way analysis of 
variance (ANOVA) was employed. Data analysis were carried out using the statistical package SPSS (Version 18).

\section{Results and discussion}

The results of the study showed that the mean of six metals $(\mathrm{Zn}, \mathrm{Cu}, \mathrm{Ni}, \mathrm{Cr}, \mathrm{Pb}$ and $\mathrm{Cd}$ ) (in microgram per liter) were lower than maximum concentrations allowed by Malaysian and international standards. Cadmium values recorded the lower value on April $(0.21 \mu \mathrm{g} / \mathrm{L})$ and the higher value on January $(0.30 \mu \mathrm{g} / \mathrm{L})$, and the average was $0.24 \pm 0.05 \mu \mathrm{g} / \mathrm{L}$. In addition, Cupper values recorded the lower value on October $(3.3 \mu \mathrm{g} / \mathrm{L})$ and the higher value on January $(3.5 \mu \mathrm{g} / \mathrm{L})$, and the average was $3.41 \pm 0.08 \mu \mathrm{g} / \mathrm{L}$. Moreover, Lead values recorded the lower value on July $(0.47 \mu \mathrm{g} / \mathrm{L})$ and the higher value on April $(0.5 \mu \mathrm{g} / \mathrm{L})$, and the average was $0.49 \pm 0.01 \mu \mathrm{g} / \mathrm{L}$. Zinc values recorded the lower value on April $(10.8 \mu \mathrm{g} / \mathrm{L})$ and the higher value on July $(11.4 \mu \mathrm{g} / \mathrm{L})$, and the average was $11.08 \pm 0.28 \mu \mathrm{g} / \mathrm{L}$. While, Chromium values recorded the lower value on July $(2.2 \mu \mathrm{g} / \mathrm{L})$ and the higher value on January $(2.7 \mu \mathrm{g} / \mathrm{L})$, and the average was $2.43 \pm 0.21 \mu \mathrm{g} / \mathrm{L}$, but Nickel values recorded the lower value on July $(2.6 \mu \mathrm{g} / \mathrm{L})$ and the higher values on January and April $(2.9 \mu \mathrm{g} / \mathrm{L})$, and the average was $2.80 \pm 0.14 \mu \mathrm{g} / \mathrm{L}$.

It was obvious that the mean metal concentrations (in micrograms per liter) in Cempaka Lake water based on monthly sampling (in descending order) for $\mathrm{Zn}$, $\mathrm{Cu}, \mathrm{Ni}, \mathrm{Cr}, \mathrm{Pb}$, and $\mathrm{Cd}$ were $11.08,3.41,2.80,2.43,0.49$ and $0.24 \mu \mathrm{g} / \mathrm{L}$ respectively. Results showed that metals concentrations were lower than maximum concentrations allowed by Malaysian and international standards as shown in table 1.

Table 1: $\quad$ Metal concentrations $(\mu \mathrm{g} / \mathrm{L})$ in the water of Cempaka Lake in 2010.

\begin{tabular}{|c|c|c|c|c|c|c|c|}
\hline Parameter & Unit & Jan & Apr & Jul & Oct & Aver & $\begin{array}{c}\text { NWQS } \\
\text { Malaysia } \\
\text { (class I) }\end{array}$ \\
\hline Temperature & ${ }^{\circ} \mathrm{C}$ & 27.7 & 27 & 28 & 27.7 & $\begin{array}{c}27.6 \pm \\
0.42\end{array}$ & \\
\hline SPC & $\mu \mathrm{S} / \mathrm{cm}$ & 1710 & 1705 & 1711 & 1710 & $\begin{array}{c}1709 \pm \\
2.71\end{array}$ & 1000 \\
\hline TDS & $\mathrm{mg} / \mathrm{L}$ & 894 & 900 & 894 & 896 & $\begin{array}{c}896 \pm \\
2.83\end{array}$ & 500 \\
\hline DO & $\mathrm{mg} / \mathrm{L}$ & 1 & 1 & 1 & 1 & $1 \pm 0.00$ & 7 \\
\hline $\mathrm{pH}$ & & 7.5 & 7.4 & 7.27 & 7.3 & $\begin{array}{c}7.37 \pm \\
0.10\end{array}$ & $6.5-8.5$ \\
\hline Hardness & $\begin{array}{c}\mathrm{CaCO}_{3} \\
\mathrm{mg} / \mathrm{L}\end{array}$ & 33.4 & 34 & 34 & 35.8 & $\begin{array}{c}34.3 \pm \\
1.04\end{array}$ & 50 \\
\hline
\end{tabular}


The study demonstrated that the water temperature values increased during the months of the study. The lower and higher values were $27.7^{\circ} \mathrm{C}$ and $28^{\circ} \mathrm{C}$ respectively, and the average was $27.6^{\circ} \mathrm{C}$. Conductivity values increased during the study period with the averages of $1709 \mu \mathrm{S} / \mathrm{cm}$, while the lower value $1705 \mu \mathrm{S} / \mathrm{cm}$. Increasing water temperature values lead to increasing the evaporation from the surface area of the lake and finally increasing the content of salts and conductivity values. Moreover, the stagnant of water in some parts of the lake may affect the electrical conductivity. The total dissolved solid values increased due to increased the electrical conductivity values and the water of the lake classified as class (II) according to NWQS Malaysia with the average of $896 \mathrm{mg} / \mathrm{L}$, while the lower and higher values were 894 and $900 \mathrm{mg} / \mathrm{L}$ respectively. Dissolved oxygen values decreased than the normal ranges with the average of $1 \mathrm{mg} / \mathrm{L}$. Moreover, the results of dissolved oxygen indicated to the number of organisms which lived in the lake and consumed the oxygen. It was very clear that $\mathrm{pH}$ values were within the normal ranges with the averages of 8.5.The lower value was 7.27 and recorded on July but higher value was 7.5 on January. In addition, the value of hydrogen ion concentration indicated that the water of Cempaka Lake was alkaline medium. The hardness values decreased during the study period with the average of $34.3 \mathrm{CaCO}_{3} \mathrm{mg} / \mathrm{L}$, and the lower and higher values were $33.4 \mathrm{CaCO}_{3} \mathrm{mg} / \mathrm{L}$ and $35.8 \mathrm{CaCO}_{3} \mathrm{mg} / \mathrm{L}$, respectively. Furthermore, hardness values indicated that the water of the lake classified as soft water as shown in table 2 .

Table 2: $\quad$ Water quality parameters of Cempaka Lake in 2010.

\begin{tabular}{|c|c|c|c|c|c|c|c|c|c|}
\hline Metal & Uni & $\mathrm{Ja}$ & $\mathrm{Ap}$ & $\mathrm{Ju}$ & $\mathrm{Oc}$ & $\mathrm{Ave}$ & $\begin{array}{c}\text { USEP- } \\
\text { Criteria } \\
\text { maximum } \\
\text { concentratio } \\
\mathrm{n}(\mathrm{CMC}) \mu \mathrm{g} / \mathrm{l}\end{array}$ & $\begin{array}{c}\text { USEP- } \\
\text { Criteria } \\
\text { continuous } \\
\text { concentratio } \\
\mathrm{n}(\mathrm{CCC}) \mu \mathrm{g} / \mathrm{l}\end{array}$ & $\begin{array}{c}\text { CCME - } \\
\text { Protectio } \\
\mathrm{n} \text { of } \\
\text { aquatic } \\
\text { life( } \mu \mathrm{g} / \mathrm{l})\end{array}$ \\
\hline $\mathrm{Cd}$ & $\begin{array}{c}\mu \mathrm{g} \\
\mathrm{L}\end{array}$ & 0.30 & 0.21 & 0.20 & 0.25 & $\begin{array}{c}0.24 \pm \\
0.05\end{array}$ & 2 & 0.25 & 0.017 \\
\hline $\mathrm{Cu}$ & $\begin{array}{c}\mu \mathrm{g} \\
/ \mathrm{L}\end{array}$ & 3.5 & 3.44 & 3.4 & 3.3 & $\begin{array}{c}3.41 \pm \\
0.08\end{array}$ & 13 & 9 & $2-4$ \\
\hline $\mathrm{Pb}$ & $\begin{array}{c}\mu \mathrm{g} \\
/ \mathrm{L}\end{array}$ & 0.49 & 0.5 & 0.47 & 0.48 & $\begin{array}{c}0.49 \pm \\
0.01\end{array}$ & 65 & 2.5 & $1-7$ \\
\hline $\mathrm{Zn}$ & $\begin{array}{c}\mu \mathrm{g} \\
\mathrm{L}\end{array}$ & 10.9 & 10.8 & 11.4 & 11.2 & $\begin{array}{c}11.08 \pm \\
0.28\end{array}$ & 120 & 120 & 30 \\
\hline $\mathrm{Cr}$ & $\begin{array}{c}\mu \mathrm{g} \\
/ \mathrm{L}\end{array}$ & 2.7 & 2.38 & 2.2 & 2.45 & $\begin{array}{c}2.43 \pm \\
0.21\end{array}$ & 570 & 74 & 8.9 \\
\hline $\mathrm{Ni}$ & $\begin{array}{c}\mu \mathrm{g} \\
/ \mathrm{L}\end{array}$ & 2.9 & 2.9 & 2.6 & 2.8 & $\begin{array}{c}2.80 \pm \\
0.14\end{array}$ & 470 & 52 & $25-150$ \\
\hline
\end{tabular}




\section{Conclusion}

The heavy metal concentration in the water are described in descending order of $\mathrm{Zn}>\mathrm{Cu}>\mathrm{Ni}>\mathrm{Cr}>\mathrm{Pb}>\mathrm{Cd}$ at all sampling sites. The present results indicate that metals concentration in Cempaka Lake were lower than the international standards for six metals. For water quality parameters, study showed that all parameters were in natural concentration range (class I) according to National Water Quality Standard (NWQS Malaysia) except for conductivity values (EC) which appeared high according to NWQS Malaysia due to increasing temperature values and consequently increasing the evaporation ratio and salt contents. Furthermore, the dissolved oxygen values decreased and indicated to the influence of the organisms on the lake.

\section{Acknowledgement}

This study has been funded by the Libyan Government under decision number $700 / 2007$.

\section{References}

[1] Kendrick, M.J., May, M.T., Plishka, M.J. \& Robinson, K.D. Metals in Biological Systems. Ellis Harwood Limited, pp. 183.1992.

[2] Forstner, U. \& Wittman, G.T.W. Metal pollution in the aquatic environment. New York: Springer - Verlag.1981.

[3] Camusso, M., Vigano, L., \& Baitstrini, R. Bioaccumulation of trace metals in rainbow trout. Ecotoxicology and Environmental Safety, 31, 133 141.1995.

[4] Namminga, H.N., \& Wilham, J. Effects of high discharge and an oil refinery cleanup operation and heavy metals in water and sediments in Skeleton Creek. Proceedings of the Oklahoma Academy of Science, 56, 133138.1976.

[5] Storelli, M.M., Storelli, A., \& D’ddabbo, R., Marano, C., Bruno, R., \& Marcotrigiano, G.O. Trace elements in loggerhead turtles (Caretta caretta) from the eastern Mediterranean Sea: Overview and evaluation. Environmental Pollution, 135, 163 - 170.2005.

[6] Kabata-Pendias, A., \& Pendias, H. Trace elements in soil and plants ( $3^{\text {rd }}$ ed). Boca Raton, FL: CRC Press. 2001.

[7] Baldantoni, D., Alfani, A., \& Tommasi, P.D. Assessment of macro and microelement accumulation capability of two aquatic plants. Environmental Pollution, 130, 149-156. 2004.

[8] APHA. Standard Methods for the Examination of Water and Waste water. $18^{\text {th }}$ edition. Washington: American Public Health Association (APHA) 1992. 